\title{
MANAGERS AND ORGANIZATIONAL CITIZENSHIP BEHAVIOR
}

\author{
Mihaela MAN \\ mihaela_man83@yahoo.com \\ “ALEXANDRU IOAN CUZA” UNIVERSITY, IAŞI, ROMANIA
}

\begin{abstract}
In this research on the one hand we analyzed the relationship that exists in terms of motivational persistence and the Big Five dimensions and, on the other hand, organizational citizenship behavior (OCB). The results show that the conscientiousness has been identified as being in a significant positive relationship with $O C B$. This result is consistent with the data provided by previous researchers. The results also indicate that three conscientiousness facets are in a positive relationship with $O C B$. These three conscientiousness facets are self-efficacy, cautiousness and orderliness. Agreeableness was not identified as being associated with OCB. At the level of the relationship between motivational persistence factors and $O C B$, we have identified a significant positive relationship with only one factor: current purpose pursuing. The OCB model has two variables that work best as predictors: high scores with regard to current purpose in terms of the pursuing-motivational persistence factor, and low scores in terms of the imagination-facet of openness to experience.
\end{abstract}

\section{KEYWORDS:}

Personality, motivational persistence, $O C B$

\section{Introduction}

This research focuses on organizational citizenship behavior (OCB). OCB is one of the most important organizational variables in conditions in which it "... supports the social and psychological environment in which task performance takes place" (Organ, 1997, p. 95). OCB has benefits in 
terms of analyses that take into account the relationship with other psychological variables (Organ, 1994; Organ \& Ryan, 1995; Schnache, Cochran \& Dumler, 1995; Borman, Penner \& Motowidlo, 2001; LePine, Erez \& Johnson, 2002; Ilies, Fulmer, Spitzmuller \& Johnson, 2009; Chiaburu, Oh, Berry, Li \& Gardner, 2010, etc.). The purpose of this research is to illustrate the relationship between OCBs and motivational persistence, and between OCBs and the Big Five broad dimensions/facets of the Big Five.

\section{The Concepts of Research}

\subsection{Organizational Citizenship Behavior}

OCB is an "... individual behavior

that is discretionary, not directly or explicitly recognized by the formal rewards system, and that in the aggregate promotes the effective functioning of the organization. By discretionary, we mean that the behavior is not an enforceable requirement of the role or the job description, that is, the clearly specificable terms of the person's employment contract with the organization; the behavior is rather a matter personal choice, such that its omission is not generally understood as punishable" (Organ, 1988, p. 4). Smith, Organ \& Near (1983) proposed two factors with regard to OCB: altruism and generalized compliance. In this research the references to OCB will be made according to the model proposed by Smith et al. (1983).

\subsection{Personality}

In this paper the references to the aspects of the five personality dimensions will be done in accordance with the Big-Five factor structure which was developed by Goldberg (1999) and by Goldberg et al. (2006). According to this, there are six facets attached to five broad personality dimensions. For example, the conscientiousness dimension has the following facets attached to it: self-efficacy, dutifulness, achievementstriving, self-discipline, cautiousness and orderliness.

As regards the personality factors seen as antecedents to the OCB, there have been a series of studies that have presented arguments in favor of these associations (Organ \& Ryan, 1995; LePine et al., 2002; Ilies et al., 2009; Chiaburu et al., 2010) and several meta-analyses that illustrate the existence of a significant relationship between the dimensions of the Big Five and professional performance for some categories of employees (Salgado, 1997; Hurtz \& Donovan, 2000; Judge \& Ilies, 2002; Dudley, Orvis, Lebiecki \& Cortina, 2006; Morgeson et al., 2007; Judge, Klinger, Simon \& Wen Fen Yang, 2008).

\subsection{Motivational Persistence}

Motivational persistence represents another concept that will be analyzed in this research. Constantin (2013, p. 11) defined motivational persistence as being the “... predisposition of a person to persist in motivation concerning the effort directed to reaching an assumed goal (once the decision of motivational implication has been made), finding the necessary personal resources for overcoming obstacles and resisting routine, stress, fatigue and other distractors". This stable personality trait has three factors: long term purpose pursuing (LTPP), current purpose pursuing (CPP) and recurrence of unattained purposes (RUP) (Constantin, Holman \& Hojbotă, 2012).

\section{The Relationship between Personality Variables and OCB}

As far as the relationship between personality factors and professional performance is concerned, the results of various meta-analyses reveal that the conscientiousness personality dimension is a predictor of professional performance for different performance criteria: Barrick \& Mount (1991); Tett, Jackson \& Rothstein (1997); Hurtz \& Donovan (2000); Dudley et al. (2006). More specifically, conscientiousness as a personality dimension has been identified as being in a positive relationship with OCB (Organ \& Ryan, 1995; LePine, Erez \& Johnson, 2002; Ilies et al., 2009; Chiaburu et al., 2010). Agreeableness has also been identified to be 
in a relationship with OCB (Ilies et al., 2009; Chiaburu et al., 2010, etc.).

The association between motivational persistence and professional performance has been analyzed by Ţuţu and Constantin (2012). The data show that two factors associated with motivational persistence are correlated with task performance - long term purpose pursuing and current purpose pursuing.

\section{Research Methodology}

\subsection{Research Hypotheses}

Hypothesis 1: There is a significant positive relationship between $\mathrm{OCB}$ and conscientiousness.

Hypothesis 2: There is a significant positive relationship between $\mathrm{OCB}$ and agreeableness.

Hypothesis 3: There is a significant positive relationship between motivational persistence/motivational persistence factors (long term purpose pursuing and current purpose pursuing) and OCB.

Hypothesis 4: There is a model of OCB that incorporates the facets of the Big Five and the factors of motivational persistence.

\subsection{Measures}

a) Organizational Citizenship Behavior Scale (Smith et al., 1983), containing 16 items. The answers to the items are evaluated on a scale of 1 to 5, 5 being very characteristic and 1 being not at all characteristic.

b) Big Five@Plus Personality Inventory developed by Constantin et al. (2013). The questionnaire contains 240 items and allows the evaluation of the five meta-factors and the 30 facets of the five meta-factors.

c) Pms 121 questionnaire (Constantin, 2013) allows the evaluation of motivational persistence. Motivational persistence assessment was done by selecting a variant on a five-point Likert scale ranging from 1 - in a very low degree to 5 - in a very high degree. The scale has three factors: long term purpose pursuing (LTPP), current purpose pursuing (CPP) and recurrence of unattained purposes (RUP).

\subsection{Participants}

Some 72 managers from the public utilities field were included in this study. Taking into account their position in the management hierarchy, $9 \%$ of the participants were from top management, $72 \%$ from middle management and $19 \%$ from third level management (team leaders). The average age of the participants was 48 years (SD 9.70).

\section{Results}

To verify the first hypothesis, we have calculated the Pearson $r$ correlation coefficient between conscientiousness/ conscientiousness facets and OCB. According to the data, there is a significant positive correlation between conscientiousness and manager's OCB. It can also be seen that OCB has a positive relationship with three conscientiousness facets: self-efficacy, cautiousness and orderliness. In this context we can say that conscientious managers tend to exhibit more OCBs.

Table no. 1

Correlation between OCB and conscientiousness/conscientiousness facets

\begin{tabular}{|l|c|c|c|c|c|c|c|c|}
\hline & $\mathbf{1}$ & $\mathbf{2}$ & $\mathbf{3}$ & $\mathbf{4}$ & $\mathbf{5}$ & $\mathbf{6}$ & $\mathbf{7}$ & $\mathbf{8}$ \\
\hline 1. OCB & 1 & & & & & & & \\
\hline 2. Self-efficacy & $.31^{* *}$ & 1 & & & & & & \\
\hline 3. Dutifulness & -.09 & -.11 & 1 & & & & & \\
\hline 4. Achievement-striving & -.03 & $.29^{* *}$ & -.09 & 1 & & & & \\
\hline 5. Self-discipline & -.08 & $-.25^{*}$ & $.46^{* *}$ & -.01 & 1 & & & \\
\hline 6. Cautiousness & $.20^{*}$ & -.02 & $.32^{* *}$ & -.05 & $.30^{* *}$ & 1 & & \\
\hline 7. Orderliness & $.26^{*}$ & .13 & $.25^{*}$ & -.01 & .15 & $.66^{* *}$ & 1 & \\
\hline 8. Conscientiousness & $.23^{*}$ & $.38^{* *}$ & $.52^{* *}$ & $.34^{* *}$ & $.48^{* *}$ & $.71^{* *}$ & $.73^{* *}$ & 1 \\
\hline
\end{tabular}


Verifying the second hypothesis has also been done by calculating the Pearson $r$ correlation coefficient between the agreeableness/agreeableness facets and
OCB. We can see in Table no. 2 that is no significant relationship between agreeableness/ agreeableness facets and OCB.

Table no. 2

Correlation between OCB and agreeableness/agreeableness facets

\begin{tabular}{|l|c|c|c|c|c|c|c|c|}
\hline & 1 & 2 & 3 & 4 & 5 & 6 & 7 & 8 \\
\hline 1. OCB & \multicolumn{1}{|c|}{1} & & & & & & & \\
\hline 2. Trust & .17 & 1 & & & & & & \\
\hline 3. Morality & -.04 & .16 & 1 & & & & & \\
\hline 4. Altruism & .02 & $.25^{*}$ & .09 & 1 & & & & \\
\hline 5. Cooperation & -.00 & -.04 & $.27^{*}$ & .20 & 1 & & & \\
\hline 6. Modesty & .09 & $-.27^{*}$ & .18 & $.21^{*}$ & $.28^{*}$ & 1 & & \\
\hline 7. Sympathy & -.03 & .03 & $-.25^{*}$ & $.22^{*}$ & -.13 & -.05 & 1 & \\
\hline 8. Agreeableness & .08 & $.43^{* *}$ & $.47^{* *}$ & $.65^{* *}$ & $.50^{* *}$ & $.57^{* *}$ & $.29^{* *}$ & 1 \\
\hline
\end{tabular}

$* * p<.01 ; * p<.05$

Verifying the third hypothesis has also been done by calculating the Pearson $r$ correlation coefficient between the motivational persistence/motivational persistence factors and OCB.

Table no. 3

Correlation between $O C B$ and motivational persistence/ motivational persistence factors

\begin{tabular}{|l|c|c|c|c|c|}
\hline & 1 & 2 & 3 & 4 & 5 \\
\hline 1. OCB & 1 & & & & \\
\hline 2. LTPP & .01 & 1 & & & \\
\hline 3. CPP & $.40^{* *}$ & .08 & 1 & & \\
\hline 4. RUP & -.12 & .00 & $.21^{*}$ & 1 & \\
\hline 5. Motivational persistence & .18 & $.57^{* *}$ & $.55^{* *}$ & $.52^{* *}$ & 1 \\
\hline
\end{tabular}

$* * \mathrm{p}<.01 ; * \mathrm{p}<.05$

The results show that there is a significant positive relationship between the CPP factor of motivational persistence and OCB (see Table no. 3), but there is no significant correlation between the other two factors of motivational persistence (long term purpose pursuing and recurrence of unattained purposes) and OCB. Consequently, we can say that managers who pursue the current purpose tend to exhibit a higher level of OCB.

The fourth hypothesis has been verified through the use of multiple regression analysis. Potential predictors being associated in blocks, the first block includes the variables: CPP - factor of motivational persistence and the imagination-facet of openness to experience as a Big Five dimension. The variables included in the first block were obtained during the preliminary analysis of the matrix correlation between OCB and the Big Five dimensions/facets of the Big Five dimensions on the one hand, and from the previous results on the other. We have also introduced a facet of openness to 
experience as a Big Five dimension, namely adventurousness, into the second block. The results show that model 1, which contains the variables CPP and imagination, explains in the best way OCB identified in the managers' category. In such a context we can say that managers with higher scores in terms of the motivational persistence factor CPP, and who also have lower scores in terms of imagination, tend to manifest more OCBs. Model 1 obtained a value of (t) $=.320$, which means that the model explains $32 \%$ of the variation of the OCB in our context, and in our professional category (Table no. 4). OCB tends to be manifested by managers who have the ability to remain focused on current activities, on activities that require voluntary control, who can resist boredom, fatigue or stress, who can compensate for depleted resources increased by the need to complete tasks which have been started or those tasks that are in progress. Also OCBs tend to be manifested in particular by those individuals who are oriented to facts, who seek realistic and immediately applicable solutions to the problems which they face, who have a tendency to be involved in concrete aspects and who are relaxed in terms of performing various practical activities.

Table no. 4

The data resulting from the multiple hierarchical regression of the predictors of organizational citizenship behavior

\begin{tabular}{|c|c|c|c|c|}
\hline & VARIABLES & B & $\begin{array}{c}\text { ERROR } \\
\text { STANDARD B }\end{array}$ & BETA \\
\hline \multirow{2}{*}{$\begin{array}{l}\overline{7} \\
\overline{0} \\
\overline{0}\end{array}$} & (CPP) & .466 & .122 & $.375^{*}$ \\
\hline & Imagination & -1.608 & .368 & $-.428^{*}$ \\
\hline \multirow{3}{*}{ 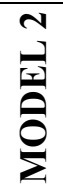 } & $(\mathrm{CPP})$ & .454 & .118 & $.366^{*}$ \\
\hline & Imagination & -1.306 & .377 & $-.348 *$ \\
\hline & Adventurousness & -.624 & .257 & $-.244 * *$ \\
\hline
\end{tabular}

*significant at the 0.01 level; ** significant at the 0.05 level

\section{Discussions}

The results obtained in this study regarding the existing association between personality factors and OCB have revealed that there is a significant relationship between conscientiousness and $\mathrm{OCB}$, a result that is in line with those obtained in previous studies (Organ \& Ryan, 1995; LePine et al., 2002; Ilies et al., 2009; Chiaburu et al., 2010). Regarding the relationship between agreeableness and $\mathrm{OCB}$, the results indicate that there is no relationship between agreeableness and OCB and likewise no relationship between agreeableness facets and OCB, results that are similar to those obtained by Organ \& Ryan (1995) and in disagreement with the results obtain by Ilies et al. (2009) and Chiaburu et al. (2010).
The results regarding the relationship between OCB (aspects of professional performance) and motivational persistence have revealed that one motivational persistence factor (CPP) shows a significant relationship with $\mathrm{OCB}$, data which are in agreement with the results obtained by Ţuţu and Constantin (2012) who took into account task performance (an aspect of professional performance).

The OCB model developed in this research has revealed the fact that the predictors of OCB are CPP - the factor of motivational persistence and imagination that are facets of openness to experience.

The results we have obtained confirm the need to focus our attention on the analysis of the five board personality 
dimensions to the level of the facets of the Big Five, just as in the case of the other dimensions contained with regard to the level of employee professional performance.

\section{Conclusions}

The conclusions of this research is that the conscientiousness has been identified as being in a significant positive relationship with $\mathrm{OCB}$, the results being found in the data provided by studies aimed at the analysis of this relationship. The results indicate also that three conscientiousness facets are in a positive relationship with OCB: self-efficacy, cautiousness and orderliness. Agreeableness has not been identified as being associated with $\mathrm{OCB}$, nor were the agreeableness facets. At the level of the relationship between motivational persistence factors and OCB we have identified a significant positive relationship only with regard to one factor: CPP. The OCB developed model has two variables as predictors that best explain it: high scores with regard to $\mathrm{CPP}$ and low scores in terms of imagination.

\section{REFERENCES}

Borman, W.C., Penner, L.A., Allen, T.D. \& Motowidlo, S.J. (2001). Personality predictors of citizenship performance. International Journal of Selection and Assessment, $9(1 / 2)$, pp. 52-69.

Chiaburu, D.S., Oh, I.S., Berry, C.M., Li, N. \& Gardner, R.G. (2010). The five-factor model of personality traits and organizational citizenship behaviors: a meta-analysis. Journal of Applied Psychology, 96(6), pp. 1-27.

Constantin, T. (2013). Manualul scalei de persistenţă motivaţională. Probă standardizată de evaluare a persistenţei motivaţionale (unpublished manuscript).

Constantin, T., Holman A. \& Hojbota, A.M. (2012). Development and validation of a motivational persistence scale. Psihologija, 2011, 45 (2), pp. 99-120.

Constantin, T., Macarie, A.E., Gheorghiu, A., Căldare, L., Fodorea, A., Iliescu, M., Hajbotă, A.M., Iordache, A., Tudose, O., Potlog, M.C., Urzică, A. \& Gavriloaiei, S. (2013). The Big Five ${ }^{\text {Oplus }}$ Inventory (unpublished manuscript).

Dudley, N.M., Orvis, K.A., Lebiecki, J.E. \& Cortina, J.M. (2006). A meta-analytic investigation of conscientiousness in the prediction of job performance: Examining the intercorrelation and the incremental validity of narrow traits. Journal of Applied Psychology, 19(1), pp. 40-57.

Goldberg, L.R. (1999). A broad-bandwidth, public-domain, personality inventory measuring the lower-level facets of several Five-Factor models. In Mervielde, I., Deary, I.J., De Fruyt, F. \& Ostendorf, F. (Eds.), Personality Psychology in Europe, (7; 7-28). Tilburg, the Netherlands: Tilburg University Press.

Goldberg, L. R., Johnson, J.A., Eber, H. W., Hogan, R., Ashton, M. C., Cloninger, C.R. \& Gough, H. G. (2006). The international personality item pool and the future of public-domain personality measures. Journal of Research in Personality, 40, pp. 84-96.

Hurtz G.M. \& Donovan J.J. (2000). Personality and Job Performance: The Big Five Revisited. Journal of Applied Psychology, 85(6), pp. 869-879.

Ilies, R., Fulmer, I.S., Spitzmuller, M. \& Johnson, M.D. (2009). Personality and citizenship behavior: the mediating role of job satisfaction. Journal of Applied Psychology, 94(4), pp. 945-959.

Judge, T.A. \& Ilies, R. (2002). Relationship of personality to performance motivation: a meta-analityc review. Journal of Applied Psychology 87(4), pp. 797-807.

Judge, T.A., Klinger, R., Simon, L.S. \& Yang, W.F. (2008). The contributions of personality to organizational behavior and psychology: findings, criticisms, and future research directions. Social and Personality Psychology Compass, 2(5), pp. 1982-2000. 
LePine, J.A., Erez, A. \& Johnson, D.E. (2002). The nature and dimensionality of organizational citizenship behavior: a critical review and meta-analysis. Journal of Applied Psychology, 87(1), pp. 52-65.

Morgeson, F.P., Campion, M.A., Dipboy, R.L., Hollenbeek, J.R., Murphy, K. \& Schmitt, N. (2007). Reconsidering the use of personality tests in personnel selection context. Personnel Psycoholy, 60(3), pp. 683-729.

Organ, D.W. (1988). Organizational citizenship behavior: The good soldier syndrome. Lexington, MA: Lexington Books.

Organ, D.W. (1994). Personality and organizational citizenship behavior. Journal of Management, 20(2), pp. 465-478.

Organ, D.W. \& Ryan, K. (1995). A meta-analytic review of attitudinal and dispositional predictors of organizational citizenship behavior. Personnel Psychology, 48(4), pp. 775-802.

Salgado, J. F. (1997). The five factor model of personality and job performance in the European Community. Journal of Applied Psychology, 82, 30-43.

Schnache, M., Cochran, D.S. \& Dumler, M.P. (1995). Encouraging organizational citizenship: The effects of job satisfaction, perceived equity and leadership. Journal of Managerial Issues, 7(2), pp. 209-221.

Smith, C.A., Organ, D.W. \& Near, J.P. (1983). Organizational citizenship behavior. Its nature and antecedents. Journal of Applied Psychology, 68(4), pp. 653-663.

Țuţu, A. \& Constantin, T. (2012). Understanding Job Performance through Persistence and job Competency. Procedias. Social and behavioral Sciences, 33, pp. 612-616. 